\title{
SISTEM INFORMASI DATA DOSEN DAN KARYAWAN PADA SEKOLAH TINGGI MANAJEMEN INFORMATIKA DAN KOMPUTER (STMIK) DUMAI
}

\author{
Elsa Pratiwi ${ }^{1}$, Sularno ${ }^{2}$, Deasy Wahyuni ${ }^{3}$ \\ ${ }^{1,2}$ Sekolah Tinggi Manajemen Informatika dan Komputer (STMIK) Dumai \\ Jalan Bukit Batrem Kota Dumai, kode pos 28811 \\ e-mail : elsapratiwi638@gmail.com ${ }^{1}, \underline{\text { sularno24@gmail.com² }} \underline{\text { deasywahyuni1@gmail.com }}^{3}$
}

\begin{abstract}
ABSTRAK
Sekolah Tinggi Manajemen Informatika dan Komputer (STMIK) Dumai merupakan salah satu kampus IT di Kota Dumai, sebelumnya, cara pengolahan data-data dosen dan karyawan pada STMIK Dumai dalam bentuk data tertulis kemudian diproses menggunakan beberapa aplikasi office dan kemudian dihasilkan sebuah informasi mengenai dosen dan karyawan, Salah satu kendala berasal dari penggunaan waktu yang relatif lama dan cenderung rentan terhadap terjadinya kesalahan.Untuk mengatasi masalah tersebut maka dibuatlah sistem informasi data dosen dan karyawan menggunakan bahasa pemograman PHP yang dapat memudahkan dosen serta karyawan dalam mengolah serta mengakses informasi yang mengenai data dosen dan karyawan pada STMIK Dumai. Metodologi dari penelitian ini adalah: Mengidentifikasi Masalah, Mengumpulkan data (Studi permasalahan, Observasi, Wawancara, Mempelajari Literatur), Menganalisis masalah, Mendesain Sistem, Membangun Sistem, Uji Coba Sistem, Penyajian Sistem. Hasil dari penelitian ini adalah Sistem ini menyajikan informasi dosen dan kepegawaian secara cepat dan akurat dan Sistem informasi ini dapat meminimalisir kehilangan data.
\end{abstract}

Kata kunci : Data, Informasi, PHP, Sistem

\begin{abstract}
The College of Informatics and Computer Management (STMIK) Dumai is one of the IT campuses in Dumai City, previously, how to process lecturer and employee data at STMIK Dumai in the form of written data then processed using several office applications and then generated information about lecturers and staff. One of the obstacles comes from the use of a relatively long time and tends to be prone to errors. To overcome this problem, a lecturer and employee data information system is made using the PHP programming language which can make it easier for lecturers and employees to process and access information regarding lecturer data. and employees at STMIK Dumai. The methodology of this research is: Identifying Problems, Collecting Data (Problem Studies, Observations, Interviews, Studying Literature), Analyzing Problems, Designing Systems, Building Systems, Testing Systems, Presentation of Systems. The results of this study are this system provides information on lecturers and staff quickly and accurately and this information system can minimize data loss.
\end{abstract}

Kata kunci : Data, Information, Systems, PHP

\section{PENDAHULUAN}

Dalam sebuah organisasi maupun institusi, perkembangan dari teknologi yang kian pesat dapat dimanfaatkan untuk menunjang kegiatan dalam organisasi dalam menyimpan dan mengolah data serta informasi.
Hal tersebut dipandang mampu menciptakan efektivitas serta efisiensi dalam mengolah data dari suatu organisasi ataupun sebuah institusi. Sebelumnya, cara pengolahan data-data dosen dan karyawan pada Sekolah Tinggi Manajemen Informatika dan Komputer 
INFORM T IK

Jurnal Informatika, Manajemen dan Komputer, Vol. 13 No. 1 , Mei 2021

eISSN : 2580-3042

pISSN : 1979-0694

(STMIK) Dumai sudah menggunakan beberapa aplikasi office, dimana biasanya dalam bentuk data-data tertulis kemudian diproses menggunakan beberapa aplikasi office dan kemudian dihasilkan sebuah informasi mengenai dosen dan karyawan.

Salah satu kekurangan diantaranya penggunaan waktu yang relatif lama, dimana memproses data sampai dihasilkannya keluaran (output) pengolahan dari data tersebut dilakukan dengan menggunakan bantuan adari beberapa aplikasi office dan cenderung rentan terhadap terjadinya kesalahan.

Selain itu informasi mengenai data-data dosen dan karyawan pada Sekolah Tinggi Manajemen Informatika dan Komputer (STMIK) Dumai tidak tersusun secara sistematis sehingga seringnya terjadi kehilangan beberapa data.

Sehingga pada pengolahan data-data dosen dan karyawan yang telah ada dikembangkan kembali dengan menambahkan kekurangan - kekurangan yang ada pada cara pengolahan data-data dosen dan karyawan dengan cara lama tersebut,dengan sistem yang dibuat dengan menggunakan bahasa pemograman Hypertext Preprocessor (PHP) yang berguna untuk memudahkan dosen serta karyawan dalam mengakses informasi yang dibutuhkan dalam pengolahan data-data dosen dan karyawan pada Sekolah Tinggi Manajemen Informatika dan Komputer (STMIK) Dumai dan dengan dibuatnya sistem informasi yang terintegrasi dengan suatu database ini menggunakan bahasa pemograman Hypertext Preprocessor (PHP) tentu sistem informasi ini membutuhkan keamanan data dengan melakukan pembatasan hak akses.

\section{a. Sistem}

Menurut Bornad dan Hopwood didalam jurnal Ni Putu Alannita dan Gusti Ngurah Agung Suaryana (Alannita and Suaryana, 2014), Sistem merupakan sekumpulan sumber daya yang saling terkait yang ingin mencapai suatu tujuan

\section{b. Database}

Menurut (Rohi Abdullah, 2018:103), Database atau basis data adalah kumpulan informasi yang disimpan dalam komputer secara sistematik sehingga dapat diperiksa meggunakan suatu program komputer untuk memperoleh informasi.

c. DFD

Menurut Serson di dalam jurnalnya (Rahman and Santoso, 2015), Data Flow Diagram (DFD) adalah diagram yang menggunakan notasi-notasi atau simbol-simbol untuk menggambarkan sistem jaringan kerja antar fungsi-fungsi yang berhubungan antara satu sama lain dengan aliran dan penyimpanan data.

\section{d. Entity Relationship Diagram (ERD)}

Menurut (Rahman et al., 2015:81), Entity Relationship Diagram adalah gambar atau diagram yang menunjukkan infomasi dibuat, disimpan dan digunakan dalam sistem bisnis.

\section{e. PHP (Hypertext Preprpcessor)}

Menurut (Dahlan, 2013) di dalam jurnalnya (Sumarni, 2015), PHP adalah singkatan dari "PHP: Hypertext Preprocessor", yang merupakan sebuah bahasa scripting yang terpasang pada HTML untuk membuat website yang dinamis.

\section{f. Contex Diagram}

Menurut (Yakup (2010:34)) di dalam jurnalnya (Suryati and Purnama, 2010), Contex Diagram (top level) adalah bagian dari data flow diagram yang berfungsi memetekan model linkungan, yang dipresentasikan dengan lingkungan tunggal yang mewakili keseluruhan sistem.

\section{METODOLOGI PENELITIAN}

Berikut ini penjelasan dari gambar kerangka kerja diatas :

1. Mengidentifikasi Masalah

Tahapan ini dimulai dengan melakukan survey ke lapangan dan melihat secara langsung bagaimana keadaan pekerjaan petugas kepegawaian yang sebenarnya

2. Mengumpulkan data

Pengumpulan data diambil dari berbagai sumber dengan tiga metode, yaitu studi permasalahan, metode observasi dan wawancara.

a. Studi permasalahan

Study permasalahan dilakukan dengan mempelajari data yang diberikan oleh petugas kepegawaian dan sampai pada pengambilan kesimpulan. Kemudian penulis akan mengkomfirmasi ulang pada bagian kepegawaian tentang keabsahan data yang diberikan. 
IN F ORM T IK A

Jurnal Informatika, Manajemen dan Komputer, Vol. 13 No. 1 , Mei 2021

eISSN : 2580-3042

pISSN : 1979-0694

b. Observasi.

Observasi dilakukan untuk melihat secara langsung bagaimana pekerjaan yang dilakukan oleh petugas kepegawaian dan memberikan pertanyaan kepada petugas kepegawaian sampai mengambil kesimpulan

c. Wawancara

Wawancara dilakukan kepada pimpinan dan petugas kepegawaian guna memperoleh data yang akan membantu dalam pembuatan aplikasi.

3. Mempelajari Literatur.

Mempelajari jurnal - jurnal serta buku - buku yang berhubungan dengan permasalahan yang ada.

4. Menganalisis masalah

Analisis masalah pada penelitian ini menggunakan dua metode, yaitu metode deskriptif dimana pada metode ini data yang ada dikumpulkan, disusun, dikelompokkan dan dianalisa sehingga diperoleh beberapa gambaran yang jelas pada permasalahan yang dibahas, dan penelitian ini juga menggunakan metode komporatif yaitu pada metode ini analisis dilakukan dengan cara membandingkan teori dan praktek, sehingga nantinya akan diperoleh gambaran yang jelas dalam pengimplementasian sistem.

5. Mendesain Sistem

Pada tahap ini akan dilakukan proses desain sistem, dimulai dengan penyajian basis data berupa fakta dan aturan, desain antar muka masukan, pembuatan algoritma, dan pembuatan antar muka keluaran.

6. Membangun Sistem

Membangun suatu sistem dengan melihat permasalahan yang ada maka dapat ditentukan kebutuhan-kebutuhan apa saja yang nantinya akan digunakan untuk kebutuhan penyimpanan data.

7. Uji Coba Sistem

Pada tahap ini dilakukan pengujian terhadap sistem yang ada terlebih dahulu sebelum dilakukan implementasi sistem

8. Penyajian Sistem

Pada tahap ini dilakukan sebuah penyajian sistem yang sudah sempurna dan dapat digunakan sesuai kebutuhan petugas kepegawaian
Adapun metodologi penelitian yang digunakan pada penelitian ini :

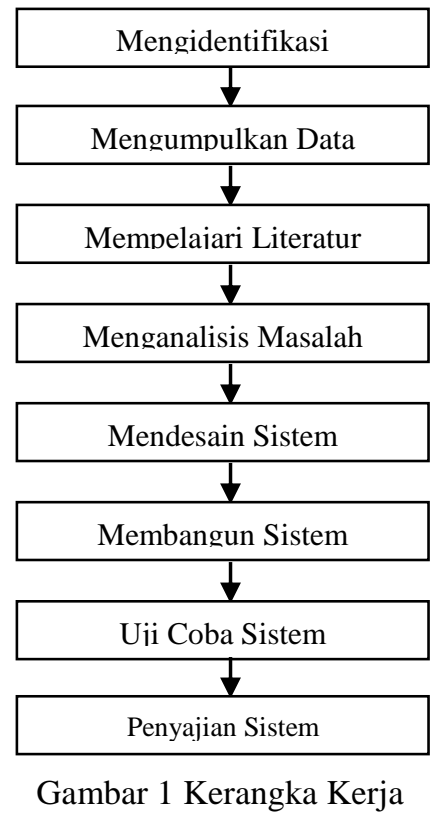

3. HASIL DAN PEMBAHASAN

a. Aliran Sitem Informasi Baru

Keterangan :

1. Dosen dan karyawan mengisi form melalui sistem dengan login masing-masing

2. Kemudian data tersebut akan masuk kedalam database yang ada

3. Selanjutnya admin kepegawaian memanggil kembali data dosen atau karyawan dari database yang digunakan untuk mencetak berkas dosen dan karyawan

4. Setelah berkas dosen dan karyawan dibuat oleh admin kepegawaian kemudian ditanda tangani oleh admin kepegawaian sebagai pembuat diserahkan kepada ketua STMIK untuk diperiksa

5. Kemudian setelah diperiksa dan dianggap rampung, berkas tersebut diarsipkan oleh petugas kepegawaian 
IN F ORM A I K A

Jurnal Informatika, Manajemen dan Komputer, Vol. 13 No. 1 , Mei 2021

eISSN : 2580-3042

pISSN : 1979-0694

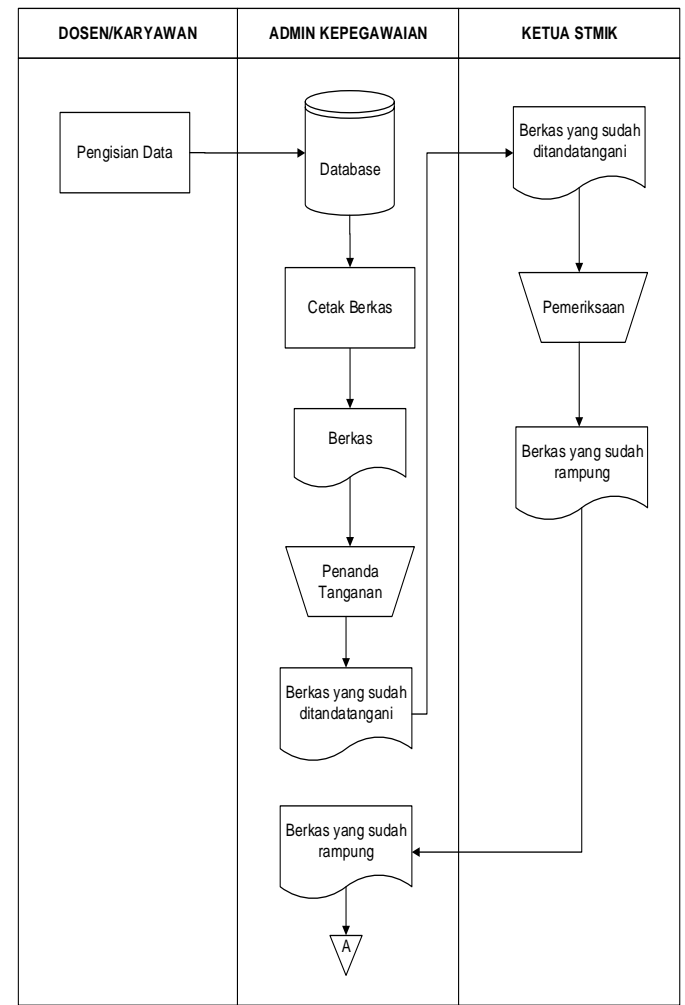

Gambar 2 Aliran Sistem Informasi Baru

\section{b. Contex Diagram}

Penjelasan dari Context Diagram dari sistem baru yang diusulkan adalah sebagai berikut :

1. Entity dosen/karyawan memberikan masukan kepada sistem berupa data dosen, data karyawan, data sertifikat penelitian dosen, data sertifikat penelitian karyawan, data prestasi dosen, data prestasi karyawan, data pengalaman mengajar dosen, data pendidikan dosen, data pendidikan karyawan data organisasi dosen, data organisasi karyawan, data judul pengabdian dosen, data judul pengabdian karyawan, data hasil penelitian dosen, dan data hasil penelitian karayawan, lalu menerima masukkan dari sistem berupa informasi dosen, informasi karyawan, informasi sertifikat penelitian dosen, informasi sertifikat penelitian karyawan, informasi prestasi dosen, informasi prestasi karyawan, informasi pengalaman mengajar dosen, informasi pendidikan dosen, informasi pendidikan karyawan informasi organisasi dosen, informasi organisasi karyawan, informasi judul pengabdian dosen, informasi judul pengabdian karyawan, informasi hasil penelitian dosen dan informasi hasil penelitian karyawan

2. Entity Admin kepegawaian menerima masukan dari sistem berupa informasi pengguna dan Admin kepegawaian memberikan masukan kepada sistem berupa data pengguna.

3. Entity Ketua menerima masukan dari sistem berupa laporan dosen, laporan karyawan, laporan sertifikat penelitian dosen, laporan sertifikat penelitian karyawan, laporan prestasi dosen, laporan prestasi karyawan, laporan pengalaman mengajar dosen, laporan pendidikan dosen, laporan pendidikan karyawan laporan organisasi dosen, laporan organisasi karyawan, laporan judul pengabdian dosen, laporan judul pengabdian karyawan, laporan hasil penelitian dosen dan laporan hasil penelitian karyawan

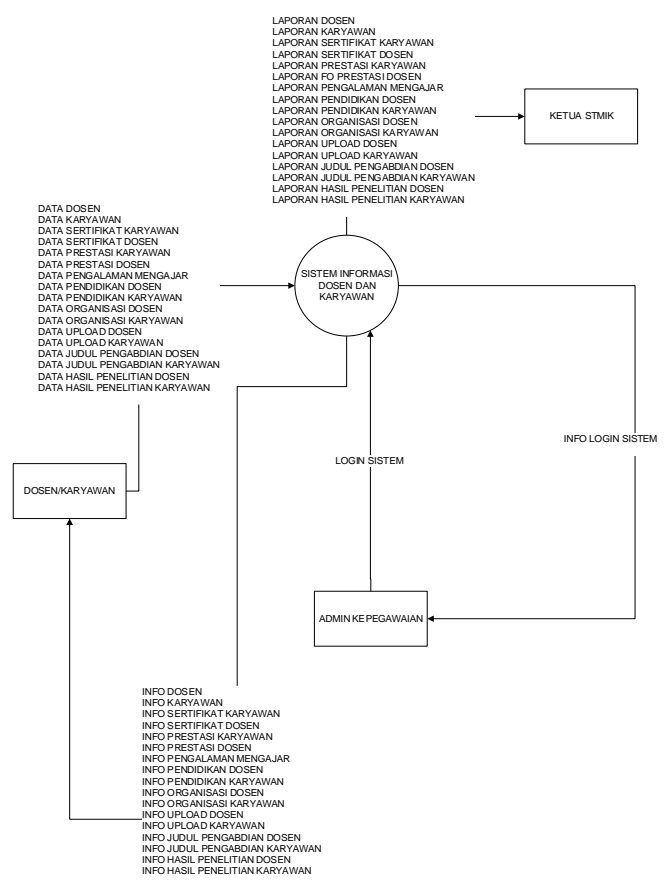

Gambar 3 Context Diagram

\section{c. DFD}

Data Flow Diagram (DFD) adalah suatu model logika data atau proses yang dibuat untuk menggambarkan dari mana asal dan kemana tujuan data yang keluar dari sistem, dimana data disimpan, proses apa saja yang menghasilkan data tersebut dan interaksi antara data yang tersimpan dan proses yang dikenakan pada data tersebut. Berikut DFD dapat dilihat pada gambar 4 dibawah ini : 
IN F ORM A I K A

Jurnal Informatika, Manajemen dan Komputer, Vol. 13 No. 1 , Mei 2021

eISSN : 2580-3042

pISSN : 1979-0694

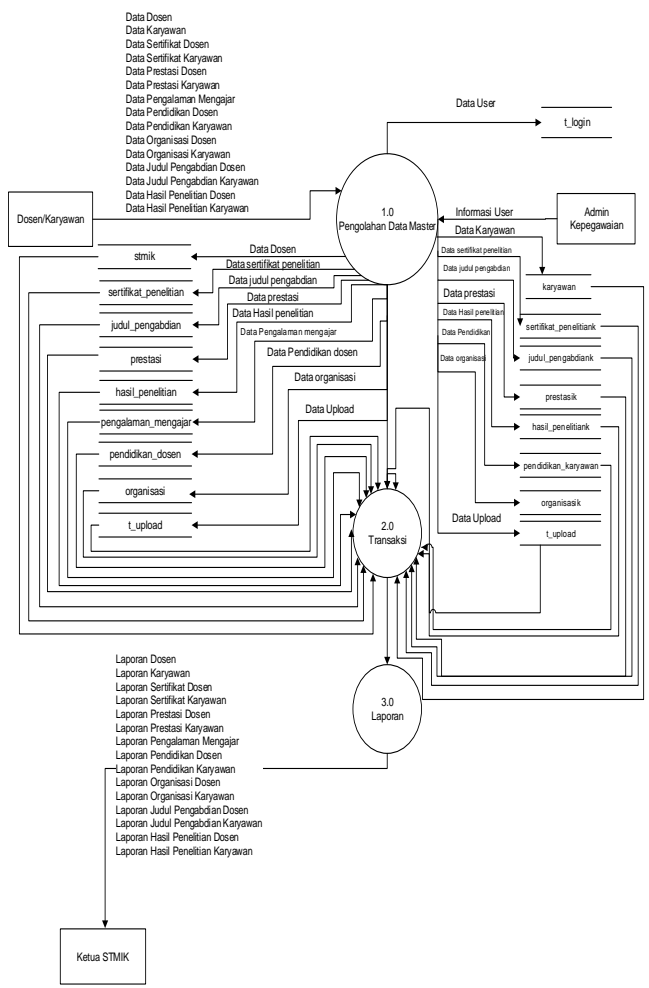

Gambar 4 DFD

\section{d. Halaman awal login}

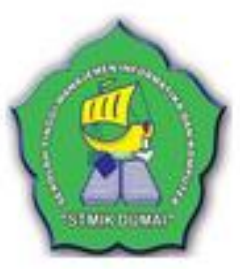

\section{is Username}

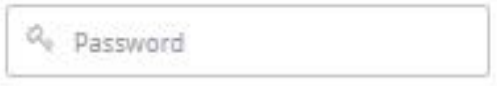

\section{LOGIN}

Gambar 5 halaman awal login

Sistem ini sebagai pengguna baik itu karyawan maupun dosen, admin kepegawaian dan ketua STMIK dengan cara membuka pada browser mozila firefox kemudian masukan alamat domain yang dituju. Masukan username dan password, jika mengisikan dengan benar maka aplikasi utama terbuka, jika belum maka lakukan registrasi terlebih dahulu dengan menghubungi admin kepegawaian

\section{e. Form Menu Utama}

Dalam menu utama terdapat submenu yang memiliki fungsi dan komponen. Klik pada menu samping untuk memasukan data dosen dan karyawan, klik pada menu samping data dosen atau karyawan.

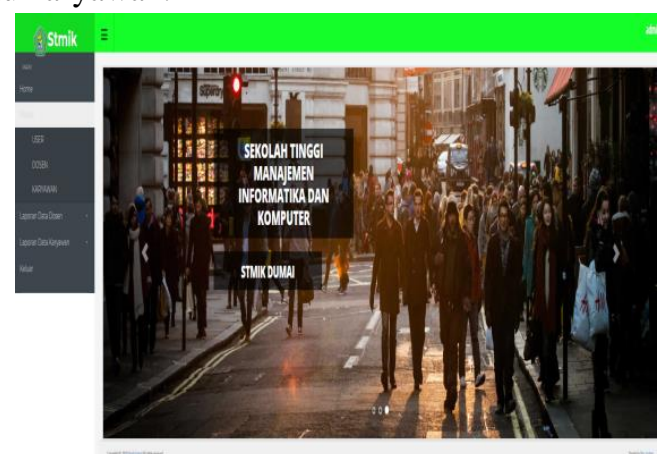

Gambar 6 Form Menu Utama

\section{g. Form Input data dosen}

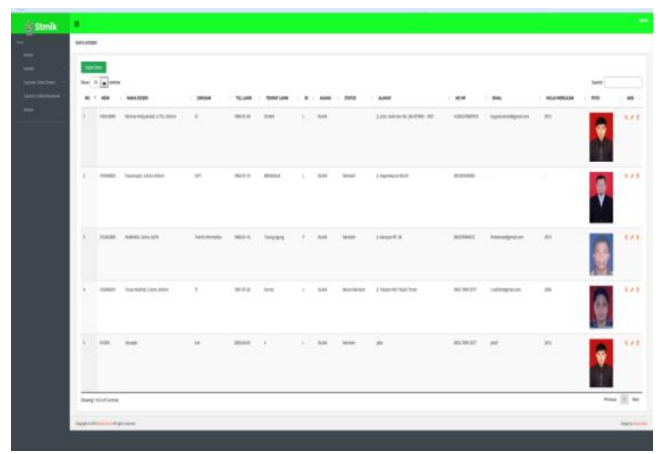

Gambar 7 Form Input Data Dosen

Pada form ini pengguna dapat menemukan data dosen dan karyawan. Dimana didalam form pengisian dosen dan karyawan terdapa sub-sub form yang harus diisi yang letaknya didalam form dosen dan karyawan. 
I N F ORM A I I A

Jurnal Informatika, Manajemen dan Komputer, Vol. 13 No. 1 , Mei 2021

eISSN : 2580-3042

pISSN : 1979-0694

\section{h. Form Input survey data dosen}

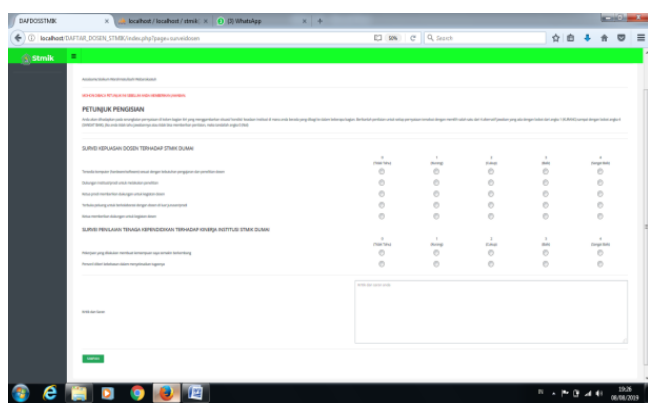

Gambar 8 Form Input survey Data Dosen

Pada form ini pengguna dapat menemukan form survey yang harus diisikan oleh dosen dan karyawan. Dimana bila dosen dan karyawan hanya dapat mengisi sekali pada masing masing form survey, bila sudah diisi maka form survey tidak akan bisa dibuka lagi oleh dosen dan karyawan.

\section{i. Form Input survey data karyawan}

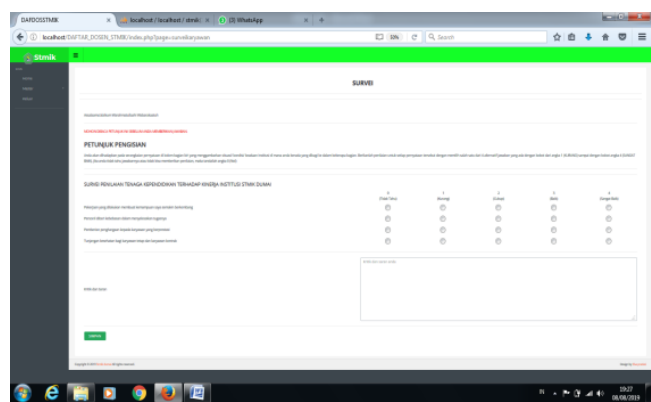

Gambar 9 Form Input survey Data Karyawan

Pada form ini pengguna dapat menemukan form survey yang harus diisikan oleh dosen dan karyawan. Dimana bila dosen dan karyawan hanya dapat mengisi sekali pada masing masing form survey, bila sudah diisi maka form survey tidak akan bisa dibuka lagi oleh dosen dan karyawan.

\section{j. Form Input data karyawan}

Pada form ini pengguna dapat menemukan data dosen dan karyawan. Dimana didalam form pengisian dosen dan karyawan terdapa sub-sub form yang harus diisi yang letaknya didalam form dosen dan karyawan.

Dimana bila karyawan sudah mengisi sekali pada masing masing form, masih bisa dilakukan revisi atau perubahan data pada masing - masing form yang ada dengan opsi yang telah disediakan yaitu menekan tombol edit yang tersedia.

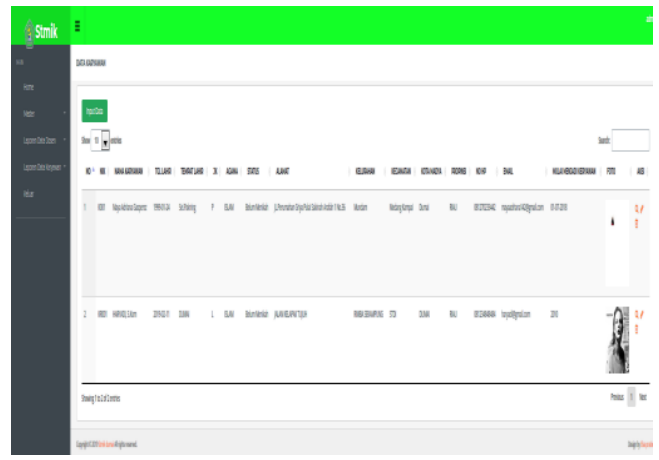

Gambar 10 Form Input Data Karyawan

\section{k. Laporan Data Dosen}

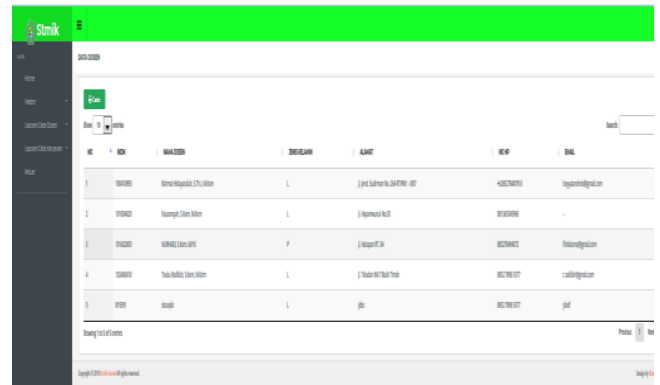

Gambar 11 Laporan Data Dosen

Pada bagian ini akan muncul nama-nama dosen, tapi ini bukan data untuk dijadikam hardcopy, untuk mendapatkan hasil hardcopy harus terlebih dahulu menekan tombol cetak

\section{Hasil Cetak Laporan Data Dosen}

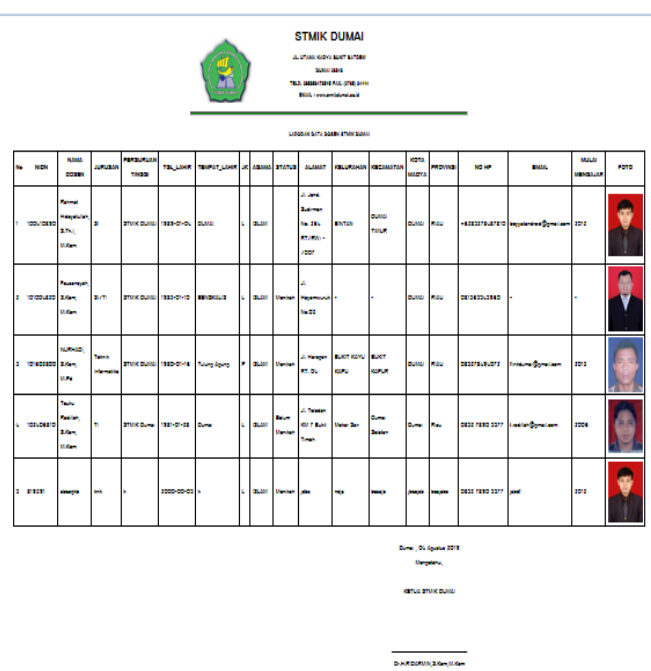

Gambar 12 Hasil Cetak Laporan Data Dosen

Ini merupakan bentuk laporan data dosen yang bisa diakses oleh admin kepegawaian, yang berisikan data-data dosen secara utuh dan 
I N F O R M A T I K A

Jurnal Informatika, Manajemen dan Komputer, Vol. 13 No. 1 , Mei 2021

eISSN : 2580-3042

pISSN : 1979-0694

keseluruhan, data pribadi maupun data pendidikan dan data pendukung lainnya.

\section{m. Laporan Data Karyawan}

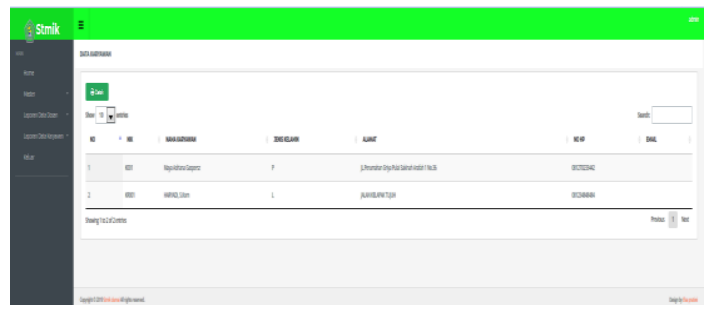

Gambar 13 Laporan Data Dosen

Pada bagian ini akan muncul nama-nama dosen, tapi ini bukan data untuk dijadikam hardcopy, untuk mendapatkan hasil hardcopy harus terlebih dahulu menekan tombol cetak

\section{n. Hasil cetak Laporan Data Karyawan}

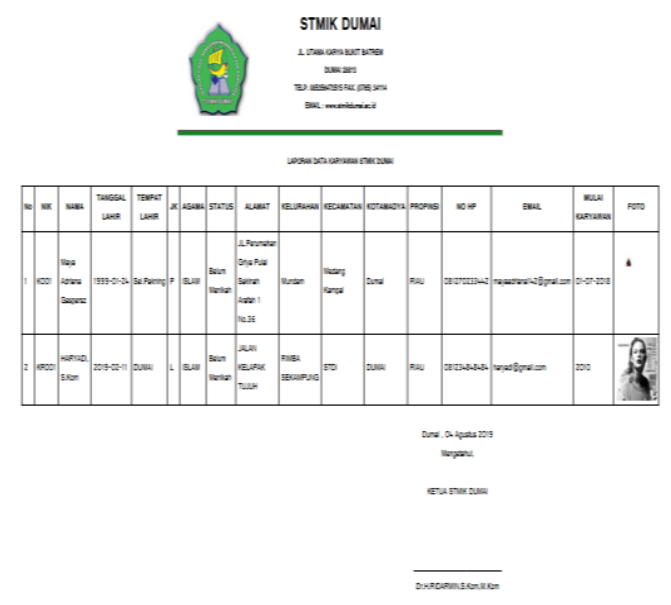

Gambar 14 Hasil Cetak Laporan Data Karyawan

Ini merupakan bentuk laporan data Karyawan yang bisa diakses oleh admin kepegawaian, yang berisikan data-data Karyawan secara utuh dan keseluruhan, data pribadi maupun data pendidikan dan data pendukung lainnya.

\section{KESIMPULAN}

Berdasarkan skripsi yang telah dibuat dengan mengamati dan menganalisa sistem informasi yang digunakan serta dilandasi oleh teori - teori yang berkaitan.

Maka dapat disimpulkan bahwa dirasakan perlu untuk diterapkannya sistem computer dengan menggunakan suatu paket aplikasi computer sebagai pengganti sistem lama yang ditangani.

Maka berdasarkan uraian-uraian di atas dan perancangan sistem di makasud di dalam skripsi ini, maka dapat diambil beberapa kesimpulan :

1. Dengan menggunakan sistem yang ini maka dapat menyajikan informasi dosen dan kepegawaian dengan cepat dan akurat.

2. Dengan adanya sistem informasi ini maka kemungkinan terjadinya kehilangan beberapa data jadi terminimalisir.

\section{REFERENSI}

Abdullah Rohi. (2018). 7 in 1 Pemrograman Web Untuk Pemula. Jakarta: PT. Elek Media Komputindo.

Alannita, N. P. and Suaryana, I. G. N. A. (2014) 'Pengaruh Kecanggihan Teknologi Informasi, Partisipasi Manajemen, Dan Kemampuan Teknik Pemakai Sistem Informasi Akuntansi Pada Kinerja Individu', E-Jurnal Akuntansi Universitas Udayana, 1(1), pp. 33-45.

Rahman, F. and Santoso (2015) 'Aplikasi pemesanan undangan online', Jurnal Sains dan Informatika, 1(1), pp. 78-87.

Sumarni, A. (2015) 'Sistem Informasi Akademik Siswa Smp Negeri Basis Kkm Dalam Bentuk Raport', Teknologi Informasi, X(29), pp. 1-7.

Suryati and Purnama, B. E. (2010) 'Pembangunan Sistem Informasi Pendataan Rakyat Miskin Untuk Program Beras Miskin ( Raskin ) Pada Desa Mantren Kecamatan Kebonagung Kabupaten Pacitan', Journal Speed Sentra Penelitian Engineering dan Edukasi, 2(4), pp. 32-41. 